\title{
The decomposition of income inequality in the EU-28
}

\author{
Stefan Kranzinger ${ }^{1}$ D
}

Published online: 25 May 2019

(c) The Author(s) 2019

\begin{abstract}
This paper analyses the structure of the European income inequality by a decomposition in a within- and between-component. It illustrates a replication of the work of Beblo and Knaus (Rev Income Wealth 47(3):301-333, 2001) and decomposes the income inequality for the EU-28 in 2014 by using data from the European Survey on Income and Living Conditions. The Theil index is applied to additively decompose the sources of inequality into a within- and between-component by countries, country groups and demographic groups. This is done by using equivalised disposable household income and income before transfers and taxes. The results show that inequality, with regard to disposable income, is highest for households with household heads older than 59 years and lowest for households with children. Moreover, high income countries have lower inequality, higher social expenditures and show a stronger relative reduction of income inequality after transfers and taxes than low income countries. On country group level, Social-Democratic countries have the lowest income inequality and redistribute most, while the opposite holds true for Baltic countries.
\end{abstract}

Keywords Theil index · Income distribution · European Union

JEL Classification D31 - D33

\section{Introduction}

The following work wants to expand and update the knowledge about the composition of the European income inequality. Therefore, it analyses the European income distribution and decomposes the Theil index in a within- and between-component.

Electronic supplementary material The online version of this article (https://doi.org/10.1007/s1066 3-019-09450-9) contains supplementary material, which is available to authorized users.

Stefan Kranzinger

stefan.kranzinger@gmx.at

1 Research Institute Economics of Inequality, Vienna University of Economics and Business, Welthandelsplatz 1, 1020 Vienna, Austria 
This approach is carried out by countries, demographic groups and country groups with similar socio-economic policies and institutions. The aim of this empirical analysis is to show the inequality within each of these groups and to illustrate their contribution to the aggregated inequality of the EU-28.

One of the most relevant studies concerning the decomposition of income inequality at the European level is carried out by Beblo and Knaus (2001). Their results show a Theil index of around 0.185 by using income data of ten European countries for the year 1995. Moreover, they find that between-country inequality contributes $3.4 \%$, for incomes before transfers and taxes, and $9.3 \%$, for disposable income, to the aggregated income inequality. A more recent approach is carried out by Hoffmeister (2009). He refers to the EU-25 and detects a convergence of national income levels and within-country personal income inequality between 1994/1995 and 1999/2000. Furthermore, he states that inequality is rising in the Social-Democratic regime but decreasing in Mediterranean welfare states. Papatheodorou and Pavlopoulos (2014) analyse the development of inequality in the EU-15 between 1996 and 2008 by calculating Theil indices. They find that the contribution of between-country inequality decreases from $14.8 \%$ in 1996 to $4.9 \%$ in 2008. Moreover, Papatheodorou and Pavlopoulos (2014) find that southern and liberal European countries show the highest inequality and relatively contribute most to aggregated inequality, whereas Scandinavian countries show the opposite result. Eurofound (2017) measures aggregated inequality for the EU-28 between 2005 and 2013 and reports a decrease in betweencountry inequality and an increase in overall inequality since 2008.

This paper contributes to the findings of Beblo and Knaus (2001). It illustrates how their results change by using income data for 2014 and including all member states of the EU-28. Moreover, an additional level of analysis is added. This paper shows also the composition of income inequality by clustering countries into groups with similar socio-economic policies and institutions. This approach should extend the results of Papatheodorou and Pavlopoulos (2014) who show how welfare state regimes could be used to explain differences in inequality among countries. ${ }^{1}$ Based on the contributions the main research questions are the following: (1) What is the composition of income inequality in the EU-28? (2) How changes the composition of income inequality in the EU-28 after transfers and taxes? To answer the first research question, equivalised disposable household income is used to calculate Theil indices. This index is additively decomposed into a within- and between-component for countries, country groups and demographic groups. The second research question is analysed by comparing the differences in the composition of income inequality between disposable income and income before transfers and taxes.

The remainder of this paper is organised as follows. Section 2 describes the underlying data of this study and illustrates the decomposition of the Theil index. The composition of income inequality is analysed in Sect. 3. Section 4 discusses the

\footnotetext{
1 The role of the welfare state regime on income distribution is argued, among others, by Atkinson et al. (1995), Gottschalk and Smeeding (1997), Smeeding and Grodner (2000), Beblo and Knaus (2001), Hoffmeister (2009) and Esping-Andersen and Myles (2011).
} 
changes of the results when using income data before transfers and taxes. Finally, Sect. 5 summarises the main findings of this study.

\section{Data and methodology}

This section presents how income is defined and manipulated for the analysis. Moreover, it is discussed how this definition and manipulation affects inequality measures and problems that occur in the collection of income data are illustrated. Furthermore, this section presents the definition of the country groups and the methodology of the decomposition of the Theil index.

\subsection{Data manipulation and the definition of income}

The results are based on the European Union Statistics on Income and Living Conditions (EU-SILC) wave of 2015. This dataset includes 555,405 observations with incomes greater than zero for the EU-28. ${ }^{2}$ The income data refers to $2014^{3}$ as, according to Atkinson and Marlier (2010), the reference period for income data in the EU-SILC is a fixed 12-month period and normally the previous calendar year in which the survey-data collection is carried out. Moreover, they mention that the only two exceptions are the United Kingdom, which defines its income reference period in the current year, and Ireland, which defines its income reference period to the last 12 months prior to the interview. ${ }^{4}$ The main variable of interest is equivalised disposable household income (HX090) ${ }^{5}$ using the "OECD-modified equivalence scale". ${ }^{6}$ This income variable reflects income after transfers and taxes and is used for calculations with regard to disposable income. To account for price differentials among countries incomes are converted into a comparable base by using purchasing power parity (PPP) exchange rates (2014) from Eurostat. Furthermore, all observations are weighted by using the personal cross-sectional weight (RB050).

To measure how the decomposition of income inequality changes after transfers and taxes in Sect. 4, equivalised market household incomes are calculated, which are defined by taking the sum of: gross employee cash (PY010G), pensions from individual private plans (PY080G) and cash benefits or losses from self-employment (PY050G) on the personal level as well as income from rental of a property or land (HY040G), regular inter-household cash transfer received (HY080G), interests,

\footnotetext{
2 The nature of the Theil allows only to use incomes greater than zero. Thus, about $0.3 \%$ of the observations are deleted due to zero or negative incomes. Moreover, observations with a personal base weight greater than zero are not considered for the analysis.

3 The only exception is Germany for which the income reference period is 2013.

4 Therefore, for the United Kingdom income is taken from the EU-SILC wave of 2014.

5 To facilitate the replication of the results the EU-SILC variable names are put in parenthesis.

6 The "OECD-modified scale" was first proposed by Hagenaars et al. (1994) who assume an equal distribution of resources within the household and assign a value of 1 to the first adult in the household, 0.5 to each additional adult member and 0.3 to each child younger than 14 years old (OECD 2013).
} 
dividends, profit from capital investment in unincorporated business (HY090G) and income received by people aged under 16 (HY110G) on the household level.

To summarise, in this study income is defined as equivalised disposable household income or equivalised market household income, respectively. Both definitions are adjusted by PPP exchange rates. Moreover, all observations are weighted by using the personal cross-sectional weight (RB050).

\subsection{Discussion}

The EU-SILC provides comparative data on income, poverty, social exclusion and living conditions in Europe. To compare income inequality among countries, country groups and demographic groups it is necessary to us the concepts of OECDmodified equivalence scale, PPP exchange rates and household heads. However, these concepts influence the degree of income inequality and are therefore discussed in the following subsection. Moreover, it is argued how in-kind benefits and the collection of income data influence inequality measures.

\subsubsection{OECD-modified equivalence scale}

The literature shows that the choice of equivalence scales influence the degree of income inequality. ${ }^{7}$ Buhmann et al. (1988) address this issue by calculating income inequality measures with different equivalence scales for ten countries using the Luxembourg Income Study database. Their results show that the chosen equivalence scales affect income inequality measures and change the ranking among countries. Similar results are found by Cowell and Mercader-Prats (1999) who show that the definition of equivalence scales influences relative differences between countries and distributional rankings. Figini (1998) show with data for Ireland, Italy, the UK and the US, that income inequality increases when putting more weight on children, whereas it decreases when the weight of adults is increased. Coulter et al. (1992) and Okamoto (2012) provide a theoretical analysis of this effect and show a U-shaped relationship between inequality measures and parameters of equivalence scales. On the other hand, Burkhauser et al. (1996) find that the use of different equivalence scales have no strong effect on inequality measures for the U.S. and Germany. However, their results indicate that equivalence scales influence the relative income level of vulnerable groups such as old single households.

\subsubsection{Purchasing power parity}

The concept of PPP influences income inequality measures and suffers from some conceptual issues that have to be considered when using them for empirical analysis. Almås (2012) finds that the poorer a country is the more its income inequality is overestimated. In addition, she shows that aggregated income inequality among

\footnotetext{
7 See among others, Schröder (2009) for an excellent discussion about the literature of equivalence scales and its applications.
} 
countries tends to be underestimated when using PPP exchange rates. Moreover, Deaton and Heston (2010) mention in particular the assumption of identical homogeneous tastes among countries, which is manifested by using the same consumption baskets for all countries among the EU-28. This might be a problem if heterogeneous countries, such as Bulgaria and France, are compared to each other. Furthermore, Milanovic (2012) shows how the adaption of PPP exchange rates in some countries causes a significant change in global inequality.

\subsubsection{Household heads}

To cluster the observations in Sect. 3.4 into demographic subgroups, the age at the end of the income reference period (PX020) is used to define household heads. Nevertheless, it has to be considered that household structures differ among the member states of EU-28, when interpreting the results in Sect. 3.4. In the dataset the average household size ranges between a value of three in Croatia to a size of around two in Germany. ${ }^{8}$ In general, household sizes tend to be larger in southern countries, while nordic countries show a smaller average household size. In addition, results of Eurostat (2015) show that in eastern and southern Europe elderly people are less likely to live in institutionalised homes compared to western and northern Europe. As collective or institutionalised households, such as old people's homes or residential homes, are not included in the EU-SILC, differences in the household structure therefore may influence the interpretation of the findings in Sect. 3.4.

There is also empirical evidence that the household structure influences the outcome of income inequality measures. Ku et al. (2018) analyse the effect of changing household structures in South Korea between 1996 and 2011. According to their results, the rise in women's labour force participation leads to a decrease in income inequality. Harkness (2010) supports this finding for OECD countries and show that higher female labour force participation decreases household income inequality. In addition, $\mathrm{Ku}$ et al. (2018) find that an increase in the age of household heads and a higher proportion of single households causes an increase of income inequality. Peichl et al. (2012) show the influence of a changing household structure on income inequality for Germany and find a link between increasing income inequality and a decrease in household size. Furthermore, Fessler et al. (2014) analyse the effect of the household structure on cross country wealth inequality and introduce an approach to account for household type fixed effects.

\subsubsection{In-kind benefits}

Paulus et al. (2010) address that the EU-SILC only provides very limited information about in-kind benefits, such as public housing subsidies, education and health care. They find that after including state benefits, which vary among the analysed countries, income inequality would be lower. Aaberge et al. (2010) show for Norway that income inequality decreases by around $15 \%$ after including in-kind benefits to

\footnotetext{
${ }^{8}$ Eurostat (2015) provides a good overview about the household structure in Europe.
} 
cash income. Furthermore, Verbist et al. (2012) argue that after the inclusion of inkind benefits income inequality decreases in the countries of the OECD. They show this effect especially for low income population groups and countries with a high degree of income inequality. However, Verbist et al. (2012) find no causal relationship between income inequality and the degree of inequality reduction after including in-kind benefits to cash income.

Moreover, the economic literature analyses the impact of imputed rents on income inequality. Törmälehto and Sauli (2013) find a reduction of income disparities when imputed rents are added to household income for European countries. Furthermore, they show that between country inequality decreases when imputed rents are considered. Frick et al. (2010) analyse the effect of imputed rents on income inequality for Belgium, Germany, Greece, Italy and the UK. Their results show that after including imputed rents, income inequality decreases within countries. However, they find that the ranking in inequality does not change among the analysed countries. Moreover, Frick et al. (2010) show that income inequality decreases especially for home-owners and the elderly, as the latter live more likely in subsidized accommodations. More recent studies from Fessler et al. (2016) and Kilgarriff et al. (2019) confirm the reducing impact of imputed rents on income inequality for Austria and Ireland, respectively.

\subsubsection{Data collection}

Like any survey, the EU-SILC suffers from problems with regard to data collection. Paturot et al. (2013) argue that low income households are more difficult to contact, are more likely to refuse to answer and might understate their income. Moreover, they state that high income households are under-represented in household survey data because they do under-report or refuse to give any information about their income. ${ }^{9}$ Because of these restrictions, income inequality tends to be underestimated.

Furthermore, the sampling design of the EU-SILC varies among countries as they can use income data out of administrative sources or directly from the household survey, which leads to limitations in comparability. ${ }^{10}$

\subsection{Definition of country groups}

This paper analyses how inequality differs between welfare state regimes and how they contribute to aggregated inequality of the EU-28. This should indicate patterns of income inequality within and between welfare state regimes. To cluster the analysed countries into groups with similar socio-economic policies and institutions,

\footnotetext{
9 See Eckerstorfer et al. (2016) for a detailed discussion and a possible adjustment of this problem within the context of wealth distribution.

10 For more details about the consequences of using income out of administrative or household survey data see among others: Jäntti et al. (2013) or Lohmann (2011).
} 
Table 1 Country groups, based on Aristei and Perugini (2015)

\begin{tabular}{|c|c|c|}
\hline Country group & Abbreviation & Countries \\
\hline Baltic countries & $\mathrm{BC}$ & Estonia, Lithuania, Latvia \\
\hline Central European economies & CEE & $\begin{array}{l}\text { Austria, Belgium, France, Germany, The Netherlands, } \\
\text { Luxembourg }\end{array}$ \\
\hline Eastern European countries & EEC & $\begin{array}{l}\text { Bulgaria, Croatia, The Czech Republic, Hungary, Poland, } \\
\text { Romania, Slovakia, Slovenia }\end{array}$ \\
\hline Liberal market economies & LME & Ireland, United Kingdom \\
\hline Mediterranean countries & MC & Cyprus, Greece, Italy, Malta, Portugal, Spain \\
\hline Social-Democratic countries & SDC & Denmark, Finland, Sweden \\
\hline
\end{tabular}

Bulgaria, Croatia, Germany, Romania and Malta are not in the framework of Aristei and Perugini (2015). Thus, these countries are clustered by taking the specific characteristics of the country groups into account

this study follows an approach of Aristei and Perugini (2015) (see Table 1). ${ }^{11}$ Their framework takes the institutional dimension of income inequality into account. It will be used to identify patterns in the income distribution and the construction of inequality on the national and European level. One main advantage compared to the pivotal work of Esping-Andersen (1990), who only distinguishes three types of welfare state regimes, is that Aristei and Perugini (2015) provide six categories of country groups. Thus, the categorization framework of Aristei and Perugini (2015) offers a more nuanced approach to cluster the member states of the EU-28. Their classification is based on the varieties of capitalism approach of Hall and Soskice (2001), who cluster countries by the distinction between liberal and coordinated market economies. This approach is extended by embedding the criticism of Coates (2000) and Amable (2003), that underlines the necessity of a broader institutional dimension. Furthermore, the classification considers literature on post-socialist states ${ }^{12}$ and is based on institutional indicators.

\subsection{Decomposing the Theil index}

To measure inequality in Europe this study uses the Theil index, an inequality measure from the generalised entropy family, that was first introduced by the seminal work of Theil (1967). ${ }^{13}$ One important feature of the Theil index is its decomposability into a within and between component. Bourguignon (1979), Cowell (1980) and Shorrocks (1980) state that the Theil index, T(1), can be decomposed into subgroups such that

\footnotetext{
${ }_{11}$ As, Bulgaria, Croatia, Germany, Romania and Malta are not in the framework of Aristei and Perugini (2015), these countries are clustered by taking the specific characteristics of the country groups into account.

${ }^{12}$ See Nölke and Vliegenthart (2009), Lane (2007), Bohle and Greskovits (2007) or Drahokoupil et al. (2008).

${ }^{13}$ For a detailed discussion of the Theil index see section A.1 in the web appendix.
} 


$$
T(1)=\underbrace{\sum_{k=1}^{K} s_{k} \times T(1)_{k}}_{\text {within component }}+\underbrace{\sum_{k=1}^{K} s_{k} \ln \left(\frac{\mu_{k}}{\mu}\right)}_{\text {between component }}
$$

with $K$, population subgroup; $s_{k}$, share of total income of subgroup k; $T(1)_{k}$, Theil index of subgroup $\mathrm{k} ; \mu$, mean income; $\mu_{k}$, mean income of subgroup k.

The first term in Eq. 1 illustrates the within-component, which is the weighted sum of the subgroup Theils $T(1)_{k}$. The second term describes the inequality that arises due to differences between subgroups $K$, which depends on the variation in mean income levels $\mu_{k}$. To weight the contribution of the respective subgroup, the total income share $s_{k}$ is used, which expresses its economic weight in the total population. According to Beblo and Knaus (2001), using a country's income share to define its contribution to total inequality is suitable as it reflects a country's economic power in Europe. However, Hoffmeister (2009) uses population share based weights, when using a similar approach, which is discussed in detail in section A.1 and A.2 in the web appendix.

\section{The decomposition of income inequality in the EU-28}

To answer the first research question of this paper, this section provides results about the decomposition of income inequality in the EU-28. Therefore, all incomes are defined as equivalised disposable household incomes and are adjusted by PPP exchange rates. First, it is presented how income is distributed in the EU-28 and among country groups. Next, the Theil index is decomposed into a within- and between-component for three different subgroups, which are defined as countries, country groups and demographic groups. This approach illustrates the contribution of inequality within and between subgroups to the aggregated inequality of the EU-28.

\subsection{The income distribution in Europe}

To draw a general picture of the income distribution in the EU-28, Fig. 1 illustrates how annual mean incomes range among income percentiles. Treating the EU-28 as one country the results show that the annual median income amounts around 16 thd EUR. Moreover, the results show a tremendous gap between the bottom and the top of the income distribution as the 1st percentile has an annual income of around 1 thd EUR, while the 99th percentile has an income of around 64 thd EUR. Thus, income is more than 64 times higher at the top compared to the bottom of the distribution. However, to know more about the structure of this distribution, it is now analysed in which income decile the single countries are located.

Table 2 gives an overview of each nation's population share within the European income distribution. Using these numbers and following an approach by 


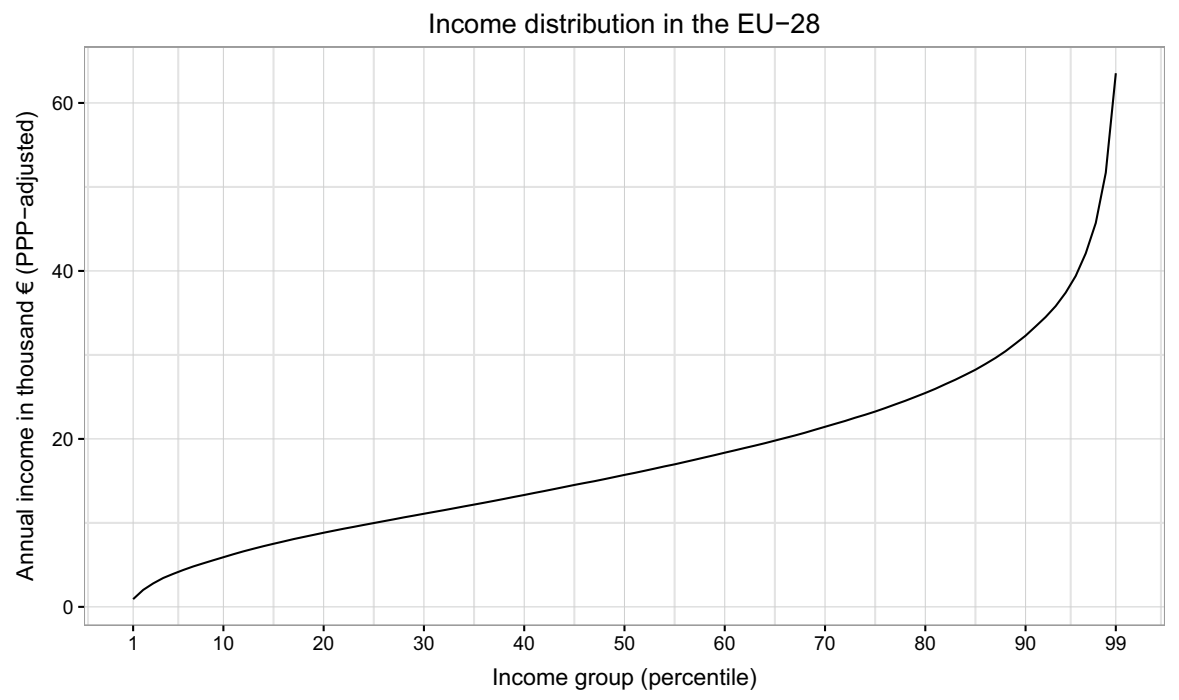

Fig. 1 Income Distribution in the EU-28 per percentile, 2014. Notes Income is defined as equivalised disposable household income and PPP-adjusted (EU-28 =1). The income reference year for Germany is 2013. Cross-sectional weights from the EU-SILC are used. This figure illustrates the income distribution in the EU-28 and shows that annual mean incomes range from around 1 thd EUR at the 1st to around 64 thd EUR at the 99th income percentile. Source: Own calculations, EU-SILC 2014 \& 2015

Beblo and Knaus (2001) an index is calculated that illustrates a country's relative representation in a certain income decile of the EU-28. A value above (below) one illustrates that the country is over-represented (under-represented) with regard to its relative population share. Germany for example amounts for around $16 \%$ of the EU-28 population. However, $4.98 \%$ of its population is in the first income decile whereas $27.65 \%$ contribute to the top income decile. Thus, Fig. 2 shows that Germany is under-represented in the lowest income decile, with an index of 0.31 but over-represented at the top, with an index of 1.72. This means that Germany has $69 \%$ less inhabitants in the lowest and $72 \%$ more inhabitants in the highest European income decile as it would be expected if its population would be equally distributed among the European income distribution.

To test if countries with similar socio-economic policies and institutions show a comparable pattern in their income distribution, this study clusters the results into six country groups. The results are plotted in Fig. 2 and illustrate that in four of the six country groups, countries show a similar pattern in their income distribution. Thus, all Social-Democratic countries (SDC), central European economies (CEE) and liberal market economies (LME) are under-represented in the first and over-represented in the tenth income decile, while Baltic countries (BC) show the opposite result. However, Mediterranean countries (MC) and eastern European countries (EEC) show a heterogeneous picture in their relative representation. Within EEC Slovenia and the Czech Republic are both under-represented at the bottom and the top of the income distribution, whereas the rest in 
Table 2 Income distribution in the EU-28 per decile among countries-population share in \%, 2014. Source: Own calculations, EU-SILC 2014 \& 2015

\begin{tabular}{|c|c|c|c|c|c|c|c|c|c|c|c|}
\hline \multirow[t]{2}{*}{ Count } & \multicolumn{10}{|c|}{ Income decile } & \multirow[t]{2}{*}{ Mean $^{\mathrm{a}}$} \\
\hline & 1 & 2 & 3 & 4 & 5 & 6 & 7 & 8 & 9 & 10 & \\
\hline AT & 0.34 & 0.36 & 0.82 & 1.06 & 1.57 & 1.90 & 2.43 & 2.73 & 2.93 & 2.84 & 1.70 \\
\hline $\mathrm{BE}$ & 0.26 & 0.80 & 1.42 & 2.20 & 2.39 & 2.47 & 2.82 & 3.39 & 3.59 & 2.86 & 2.22 \\
\hline BG & 5.35 & 3.77 & 1.96 & 1.21 & 0.75 & 0.47 & 0.28 & 0.23 & 0.21 & 0.24 & 1.45 \\
\hline CY & 0.06 & 0.19 & 0.25 & 0.22 & 0.18 & 0.18 & 0.18 & 0.15 & 0.13 & 0.15 & 0.17 \\
\hline $\mathrm{CZ}$ & 1.09 & 3.28 & 4.63 & 3.76 & 2.96 & 1.99 & 1.20 & 0.80 & 0.51 & 0.49 & 2.07 \\
\hline $\mathrm{DE}$ & 4.98 & 6.47 & 9.59 & 11.91 & 15.38 & 18.55 & 20.18 & 20.97 & 24.67 & 27.65 & 16.03 \\
\hline DK & 0.32 & 0.22 & 0.32 & 0.71 & 1.18 & 1.40 & 1.57 & 1.83 & 2.02 & 1.71 & 1.13 \\
\hline $\mathrm{EE}$ & 0.41 & 0.57 & 0.33 & 0.30 & 0.26 & 0.20 & 0.17 & 0.14 & 0.12 & 0.11 & 0.26 \\
\hline EL & 5.31 & 5.04 & 3.46 & 2.51 & 1.79 & 1.25 & 0.93 & 0.55 & 0.36 & 0.30 & 2.15 \\
\hline ES & 10.23 & 9.92 & 9.88 & 9.84 & 9.70 & 9.48 & 8.44 & 8.54 & 8.03 & 8.14 & 9.22 \\
\hline FI & 0.10 & 0.30 & 0.68 & 1.11 & 1.25 & 1.46 & 1.56 & 1.63 & 1.52 & 1.20 & 1.08 \\
\hline FR & 1.45 & 3.90 & 8.70 & 11.25 & 13.78 & 15.99 & 17.94 & 17.70 & 16.71 & 17.77 & 12.52 \\
\hline HR & 2.14 & 2.19 & 1.42 & 0.99 & 0.67 & 0.43 & 0.25 & 0.14 & 0.11 & 0.05 & 0.84 \\
\hline $\mathrm{HU}$ & 5.07 & 6.15 & 3.37 & 2.12 & 1.15 & 0.65 & 0.43 & 0.25 & 0.15 & 0.09 & 1.94 \\
\hline IE & 0.18 & 0.32 & 0.76 & 0.96 & 1.09 & 1.02 & 1.00 & 1.22 & 1.27 & 1.50 & 0.93 \\
\hline IT & 10.02 & 10.89 & 12.94 & 13.26 & 13.44 & 13.94 & 13.56 & 12.97 & 10.96 & 9.99 & 12.20 \\
\hline LT & 1.67 & 1.35 & 0.70 & 0.62 & 0.51 & 0.34 & 0.22 & 0.19 & 0.11 & 0.15 & 0.59 \\
\hline LU & 0.01 & 0.01 & 0.01 & 0.03 & 0.05 & 0.07 & 0.10 & 0.13 & 0.20 & 0.43 & 0.10 \\
\hline LV & 1.14 & 0.89 & 0.55 & 0.40 & 0.32 & 0.21 & 0.13 & 0.12 & 0.10 & 0.07 & 0.39 \\
\hline MT & 0.01 & 0.07 & 0.10 & 0.09 & 0.10 & 0.10 & 0.10 & 0.10 & 0.09 & 0.08 & 0.08 \\
\hline NL & 0.54 & 0.91 & 1.70 & 3.28 & 4.13 & 4.39 & 5.06 & 5.01 & 4.52 & 4.07 & 3.36 \\
\hline PL & 13.69 & 18.11 & 14.02 & 9.67 & 6.65 & 4.50 & 3.22 & 2.28 & 1.59 & 1.19 & 7.49 \\
\hline PT & 3.42 & 4.20 & 3.29 & 2.79 & 2.14 & 1.51 & 1.07 & 0.89 & 0.75 & 0.73 & 2.08 \\
\hline RO & 26.44 & 8.58 & 2.66 & 1.25 & 0.54 & 0.15 & 0.04 & 0.03 & 0.00 & 0.04 & 3.97 \\
\hline SE & 0.43 & 0.57 & 1.06 & 1.62 & 1.85 & 2.31 & 2.73 & 3.17 & 3.38 & 2.39 & 1.95 \\
\hline SI & 0.13 & 0.38 & 0.42 & 0.53 & 0.64 & 0.65 & 0.50 & 0.37 & 0.25 & 0.15 & 0.40 \\
\hline SK & 1.15 & 2.30 & 2.44 & 1.86 & 1.38 & 0.69 & 0.37 & 0.17 & 0.08 & 0.06 & 1.05 \\
\hline UK & 4.05 & 8.25 & 12.50 & 14.45 & 14.17 & 13.84 & 13.40 & 14.41 & 15.58 & 15.55 & 12.62 \\
\hline
\end{tabular}

Income is defined as equivalised disposable household income and PPP-adjusted (EU-28 $=1$ ). The income reference year for Germany is 2013. Cross-sectional weights from the EU-SILC are used

The numbers in this table illustrate a country's population in the respective income decile of the EU-28 in percentage terms

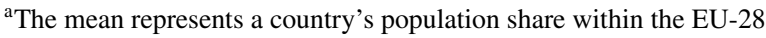




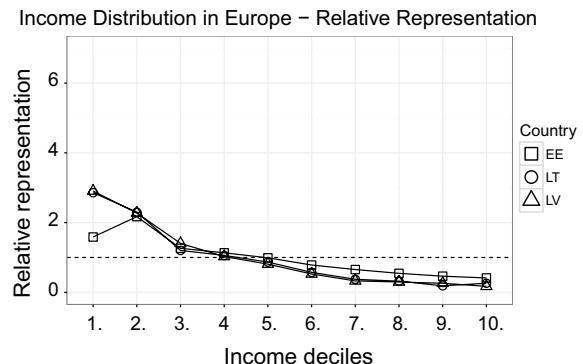

(a) Baltic countries

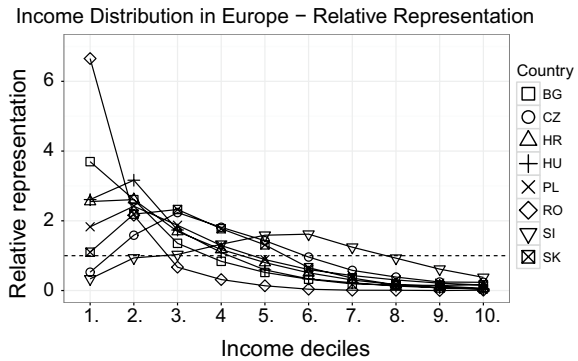

(c) Eastern European countries

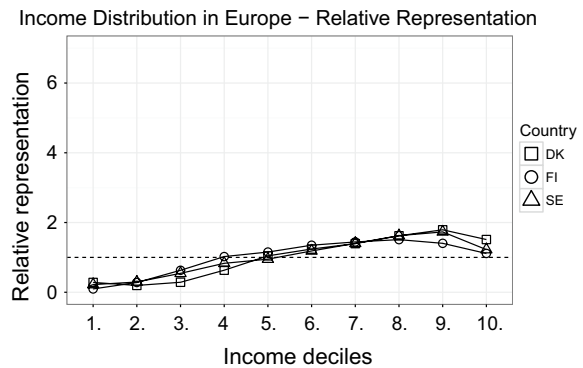

(e) Social democratic countries

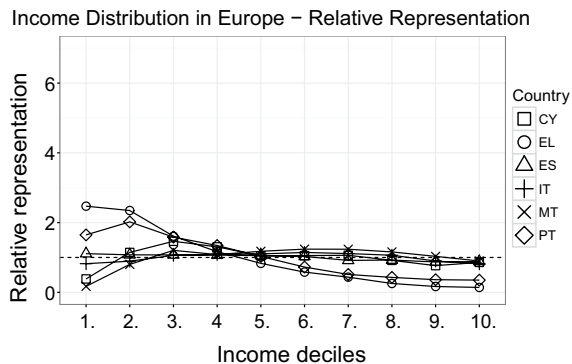

(b) Mediterranean countries

Income Distribution in Europe - Relative Representation

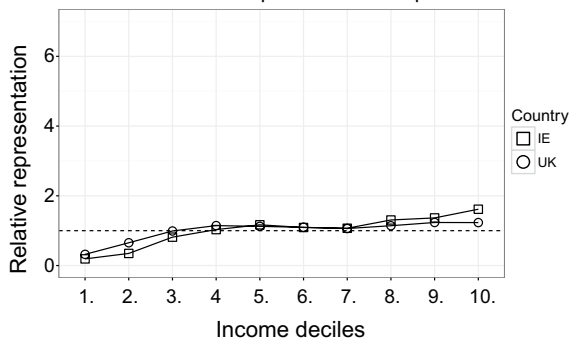

(d) Liberal market economies

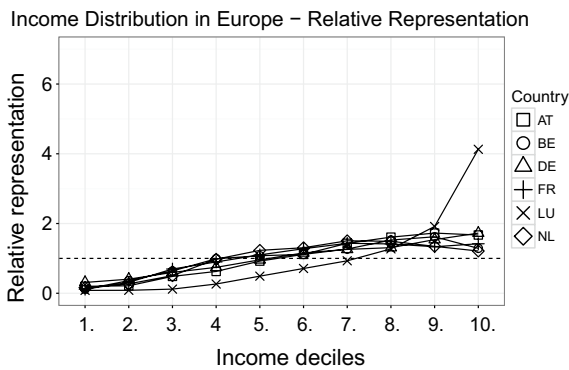

(f) Central European economies

Fig. 2 Income distribution in the EU-28 per decile among country groups-relative representation, 2014. Notes Based on Aristei and Perugini (2015), countries are clustered into country groups with regard to similar socio-economic policies and institutions. Income is defined as equivalised disposable household income and PPP-adjusted (EU-28 = 1). The income reference year for Germany is 2013. Cross-sectional weights from the EU-SILC are used. The index on the y-axis illustrates a country's relative representation in a certain income decile of the EU-28. A value above (below) one illustrates that the country is over-represented (under-represented) with regard to its relative population share. The results show that CEE, LME and SDC are overrepresented at the tenth and underrepresented at the first income decile, whereas BC show the opposite result. Moreover, two countries stand out. Luxembourg has more than four times more people at the top, while Romania shows over six times more people at the bottom of the income distribution, as we would expect if their populations would be equally distributed among the European income distribution. Source: Own calculations, EU-SILC 2014 \& 2015 
Table 3 Sources of income inequality in the EU-28 by country, 2014. Source Own calculations, EUSILC 2014 \& 2015

\begin{tabular}{|c|c|c|c|c|}
\hline Country & Theil index & $\begin{array}{l}\text { Annual mean income in } \\
\text { thd EUR }\end{array}$ & $\begin{array}{l}\text { Inequality share }{ }^{a} \\
(\%)\end{array}$ & $\begin{array}{l}\text { Economic } \\
\text { weight }^{\text {b }} \\
(\%)\end{array}$ \\
\hline AT & 0.141 & 24 & 1.5 & 2.2 \\
\hline $\mathrm{BE}$ & 0.121 & 21.9 & 1.5 & 2.6 \\
\hline BG & 0.251 & 8.9 & 0.8 & 0.7 \\
\hline $\mathrm{CY}$ & 0.233 & 18.4 & 0.2 & 0.2 \\
\hline $\mathrm{CZ}$ & 0.114 & 13.3 & 0.8 & 1.5 \\
\hline DE & 0.162 & 23.4 & 15.3 & 20.3 \\
\hline DK & 0.158 & 23.8 & 1.1 & 1.5 \\
\hline $\mathrm{EE}$ & 0.196 & 13.4 & 0.2 & 0.2 \\
\hline EL & 0.211 & 10.6 & 1.2 & 1.2 \\
\hline ES & 0.195 & 17.3 & 7.9 & 8.7 \\
\hline FI & 0.112 & 21.3 & 0.7 & 1.3 \\
\hline FR & 0.165 & 22.8 & 12.0 & 15.6 \\
\hline HR & 0.156 & 9.7 & 0.3 & 0.4 \\
\hline $\mathrm{HU}$ & 0.138 & 9.1 & 0.6 & 1.0 \\
\hline IE & 0.152 & 22.4 & 0.8 & 1.1 \\
\hline IT & 0.178 & 18 & 9.8 & 11.9 \\
\hline LT & 0.258 & 11 & 0.4 & 0.3 \\
\hline LU & 0.143 & 33.2 & 0.1 & 0.2 \\
\hline LV & 0.211 & 10.4 & 0.2 & 0.2 \\
\hline MT & 0.136 & 19.1 & 0.1 & 0.1 \\
\hline NL & 0.133 & 21.9 & 2.5 & 4.0 \\
\hline PL & 0.163 & 11.1 & 3.5 & 4.6 \\
\hline PT & 0.204 & 12.7 & 1.4 & 1.4 \\
\hline RO & 0.430 & 5.4 & 2.3 & 1.2 \\
\hline SE & 0.110 & 22 & 1.2 & 2.3 \\
\hline SI & 0.102 & 16.5 & 0.2 & 0.4 \\
\hline SK & 0.099 & 11 & 0.3 & 0.6 \\
\hline UK & 0.177 & 20.6 & 11.6 & 14.2 \\
\hline Between countries & - & - & 21.7 & - \\
\hline Europe & 0.215 & 18.4 & 100 & 100 \\
\hline
\end{tabular}

Income is defined as equivalised disposable household income and PPP-adjusted $(\mathrm{EU}-28=1)$. The income reference year for Germany is 2013. Cross-sectional weights from the EU-SILC are used

${ }^{a}$ The inequality share represents the contribution of a country to the overall inequality of the EU-28

${ }^{\mathrm{b}}$ The economic weight describes the income share of a country with regard to the overall income of the EU-28

this country group is over-represented at the bottom and under-represented at the top. Moreover, especially with regard to the lowest income decile, MC split into two poles as Cyprus, Italy and Malta are heavily under-represented, while Greece, Portugal and Spain are over-represented at the bottom of the income distribution. 
Table 4 The Theil index in a growing Europe

\begin{tabular}{lcccc}
\hline Source & Year & Countries & Theil-index & $\begin{array}{l}\text { Between coun- } \\
\text { try inequality } \\
\text { in \% }\end{array}$ \\
\hline $\begin{array}{l}\text { Beblo and Knaus (2001) } \\
\begin{array}{l}\text { Papatheodorou and Pavlopoulos } \\
(2014)\end{array}\end{array}$ & 1995 & EU-10 & 0.185 & 9.30 \\
\begin{tabular}{l} 
Own results \\
\hline
\end{tabular} & 2008 & EU-15 & 0.148 & 4.90 \\
\hline
\end{tabular}

EU-10: AT, BG, DE, ES, FR, IR, IT, LU, NL, PT; EU-15: EU-10 + DK, EL, FI, SE, UK; EU-28: EU-15 $+\mathrm{BE}, \mathrm{CY}, \mathrm{CZ}, \mathrm{EE}, \mathrm{HR}, \mathrm{HU}, \mathrm{LT}, \mathrm{LV}, \mathrm{MT}, \mathrm{PL}, \mathrm{RO}, \mathrm{SI}, \mathrm{SK}$

Table 5 Sources of income inequality in the EU-28 by country group, 2014. Source: Own calculations, EU-SILC 2014 \& 2015

\begin{tabular}{lllll}
\hline Country group & Theil index & $\begin{array}{l}\text { Annual mean income } \\
\text { in thd EUR }\end{array}$ & $\begin{array}{l}\text { Inequality } \\
\text { share }(\%)\end{array}$ & $\begin{array}{l}\text { Economic } \\
\text { weight }^{\mathrm{b}} \\
(\%)\end{array}$ \\
\hline BC & 0.233 & 11.3 & 0.8 & 0.8 \\
CEE & 0.158 & 23 & 33.0 & 45.0 \\
EEC & 0.223 & 9.9 & 10.7 & 10.4 \\
LME & 0.175 & 20.8 & 12.5 & 15.3 \\
MC & 0.198 & 16.7 & 21.7 & 23.5 \\
SDC & 0.125 & 22.3 & 2.9 & 5.1 \\
Between country group & 0.040 & - & 18.4 & - \\
Europe & 0.215 & 18.4 & 100 & 100 \\
\hline
\end{tabular}

Income is defined as equivalised disposable household income and PPP-adjusted (EU-28 $=1$ ). The income reference year for Germany is 2013. Cross-sectional weights from the EU-SILC are used

${ }^{a}$ The inequality share represents the contribution of a country group to the overall inequality of the EU-28

${ }^{\mathrm{b}}$ The economic weight describes the income share of a country group with regard to the overall income of the EU-28

On country level, the results show two interesting findings, which picture the differences in income between the member states of the EU. In the first decile, Romania is heavily over-represented and shows an index of 6.6, whereas Luxembourg shows an index of 4.3 for the top income decile.

\subsection{Decomposition by countries}

This study now turns to the decomposition of the Theil index. Table 3 refers to country-Theils which vary between a value of 0.099 in Slovenia and 0.430 in Romania. Moreover, Table 3 shows each country's contribution to the aggregated inequality of 0.215 in the EU-28. The results indicate that the largest five countries Germany, the United Kingdom, France, Italy and Spain are responsible for $56.6 \%$ of 
the aggregated Theil index. The between-component accounts for $21.7 \%$. Thus, it follows that the remaining $21.7 \%$ are due to the other 23 countries.

Table 4 compares the results of this paper with former studies that calculate the Theil index by using equivalised disposable household income. Beblo and Knaus (2001) analyse the founding countries of the European Monetary Union for 1995. They show that between-country inequality account for $9.3 \%$ to the inequality measure of 0.185. A more recent study of Papatheodorou and Pavlopoulos (2014) for the EU-15 in 2008 shows a Theil index of 0.148 and a contribution of between-country differences of $4.9 \%$. However, the results in this section show that for the EU-28 the aggregated income inequality increases to 0.215 . In addition, the relative contribution of between-country differences increases to $21.7 \%$.

\subsection{Decomposition by country groups}

This study now analyses the contribution of inequality within- and between-countrygroups with similar socio-economic policies and institutions. ${ }^{14}$ Table 5 illustrates that country groups divide into two poles. The lowest inequality is found in SDC (0.125) followed by CEE (0.158) and LME (0.175), which are the three country groups with the highest annual mean incomes. On the other hand, inequality is highest in BC (0.233), EEC (0.223) and MC (0.198), which are the country groups with the lowest annual mean incomes. Thus, high income country groups show lower income inequality compared to low income country groups.

\subsection{Decomposition by demographic groups}

This subsection shows the contribution of demographic subgroups to income inequality with a decomposition by household types. Therefore, this study uses an approach of Beblo and Knaus (2001) where the sample is split into three groups. The first group consists of households with household heads ${ }^{15}(\mathrm{hh})$ older than 59 years. Households with hh younger than 60 are divided into households without and with children respectively. This simple categorization shows how income inequality varies among specific population groups in a country and which subgroup contributes most to overall inequality.

\subsubsection{Demographic groups on country level}

Table 6 shows that hh with children (0.200) have the lowest, whereas hh above 59 (0.229) have the highest income inequality in the EU-28. The same result is found by Beblo and Knaus (2001), who argue that in most social protection systems, pensions depend on former gross-earnings and therefore reflect past income inequality. Moreover, income inequality of households with hh above 59 years show the largest

\footnotetext{
14 All inhabitants of a country group are treated as they would live in a single country. Moreover, personal cross-sectional weights are used to adjust for the country size.

15 The household head is defined as the person with the highest income of at least 18 years of age. When two household members have the same income, the oldest person is chosen to be the household head.
} 
Table 6 Sources of income inequality in the EU-28 by country and demographic type, 2014. Source: Own calculations, EU-SILC 2014 \& 2015

\begin{tabular}{|c|c|c|c|c|}
\hline \multirow[t]{2}{*}{ Country } & \multicolumn{3}{|c|}{ Age of the household head ${ }^{\mathrm{a}}$} & \multirow[t]{2}{*}{ All } \\
\hline & $\begin{array}{l}<60, \text { without } \\
\text { children }\end{array}$ & $<60$, children & $\geq 60$ & \\
\hline AT & 0.135 & 0.122 & 0.161 & 0.141 \\
\hline $\mathrm{BE}$ & 0.116 & 0.099 & 0.157 & 0.121 \\
\hline BG & 0.210 & 0.275 & 0.259 & 0.251 \\
\hline CY & 0.218 & 0.215 & 0.307 & 0.233 \\
\hline $\mathrm{CZ}$ & 0.109 & 0.127 & 0.075 & 0.114 \\
\hline $\mathrm{DE}$ & 0.174 & 0.147 & 0.147 & 0.162 \\
\hline DK & 0.161 & 0.147 & 0.165 & 0.158 \\
\hline $\mathrm{EE}$ & 0.183 & 0.190 & 0.171 & 0.196 \\
\hline EL & 0.209 & 0.230 & 0.182 & 0.211 \\
\hline ES & 0.184 & 0.211 & 0.187 & 0.195 \\
\hline FI & 0.122 & 0.081 & 0.133 & 0.112 \\
\hline FR & 0.166 & 0.125 & 0.209 & 0.165 \\
\hline HR & 0.148 & 0.135 & 0.183 & 0.156 \\
\hline $\mathrm{HU}$ & 0.144 & 0.131 & 0.120 & 0.138 \\
\hline IE & 0.152 & 0.144 & 0.166 & 0.152 \\
\hline IT & 0.166 & 0.176 & 0.187 & 0.178 \\
\hline LT & 0.234 & 0.300 & 0.188 & 0.258 \\
\hline LU & 0.147 & 0.148 & 0.120 & 0.143 \\
\hline LV & 0.190 & 0.206 & 0.227 & 0.211 \\
\hline NL & 0.137 & 0.120 & 0.145 & 0.133 \\
\hline PL & 0.161 & 0.162 & 0.161 & 0.163 \\
\hline PT & 0.206 & 0.186 & 0.223 & 0.204 \\
\hline RO & 0.199 & 0.241 & 1.098 & 0.430 \\
\hline SE & 0.128 & 0.078 & 0.125 & 0.110 \\
\hline SI & 0.099 & 0.094 & 0.120 & 0.102 \\
\hline SK & 0.085 & 0.115 & 0.070 & 0.099 \\
\hline UK & 0.194 & 0.151 & 0.149 & 0.177 \\
\hline Europe & 0.215 & 0.200 & 0.229 & 0.215 \\
\hline
\end{tabular}

Income is defined as equivalised disposable household income and PPP-adjusted (EU-28 = 1). The income reference year for Germany is 2013. Cross-sectional weights from the EU-SILC are used

Malta had to be excluded because it does not report information about the age of individuals

${ }^{\text {a }}$ The household head is defined as the person with the highest income of at least 18 years of age. When two household members have the same income, the oldest person is chosen to be the household head

span among demographic groups and range between a Theil index of 0.070 in Slovakia and 1.098 in Romania. The other two demographic groups show a smaller span and range between a Theil index of 0.085 in Slovakia and 0.234 in Lithuania, for hh without children, and between 0.078 in Sweden and 0.300 in Lithuania, for 
Table 7 Contribution to income inequality in the EU-28 by country and demographic group, 2014. Source: Own calculations, EU-SILC 2014 \& 2015

\begin{tabular}{|c|c|c|c|c|}
\hline \multirow[t]{3}{*}{ Country } & \multicolumn{4}{|c|}{ Contribution to country inequality in $\%$} \\
\hline & \multicolumn{3}{|c|}{ Age of the household head ${ }^{a}$} & \multirow{2}{*}{$\begin{array}{l}\text { Variation } \\
\text { between } \\
\text { hh }\end{array}$} \\
\hline & $\begin{array}{l}<60, \text { with- } \\
\text { out children }\end{array}$ & $<60$, children & $\geq 60$ & \\
\hline AT & 48.98 & 25.16 & 22.80 & 3.05 \\
\hline $\mathrm{BE}$ & 43.02 & 30.00 & 24.37 & 2.61 \\
\hline BG & 40.20 & 38.94 & 16.85 & 4.01 \\
\hline $\mathrm{CY}$ & 42.44 & 34.96 & 22.17 & 0.43 \\
\hline $\mathrm{CZ}$ & 44.29 & 40.28 & 11.59 & 3.84 \\
\hline $\mathrm{DE}$ & 51.62 & 25.77 & 21.26 & 1.35 \\
\hline DK & 42.99 & 33.27 & 23.34 & 0.40 \\
\hline $\mathrm{EE}$ & 40.73 & 39.80 & 13.58 & 5.90 \\
\hline EL & 43.97 & 34.80 & 20.43 & 0.79 \\
\hline ES & 42.52 & 36.15 & 20.59 & 0.75 \\
\hline FI & 46.38 & 24.75 & 27.90 & 0.97 \\
\hline FR & 38.70 & 27.19 & 32.51 & 1.60 \\
\hline HR & 44.74 & 30.35 & 20.54 & 4.37 \\
\hline $\mathrm{HU}$ & 51.22 & 29.69 & 17.29 & 1.80 \\
\hline IE & 36.39 & 44.58 & 18.04 & 0.99 \\
\hline IT & 41.86 & 29.87 & 26.47 & 1.79 \\
\hline LT & 42.31 & 42.45 & 12.13 & 3.11 \\
\hline $\mathrm{LU}$ & 47.31 & 37.29 & 14.73 & 0.67 \\
\hline LV & 40.40 & 38.88 & 16.43 & 4.29 \\
\hline NL & 43.20 & 32.57 & 24.03 & 0.19 \\
\hline PL & 43.06 & 39.82 & 16.31 & 0.81 \\
\hline PT & 42.36 & 31.11 & 26.00 & 0.54 \\
\hline RO & 20.05 & 18.77 & 59.71 & 1.48 \\
\hline SE & 45.57 & 26.64 & 26.49 & 1.30 \\
\hline SI & 44.58 & 34.60 & 19.99 & 0.83 \\
\hline SK & 43.73 & 40.17 & 9.85 & 6.26 \\
\hline UK & 50.51 & 29.57 & 16.53 & 3.40 \\
\hline $\begin{array}{l}\text { Variation } \\
\text { between coun- } \\
\text { tries, } \%\end{array}$ & 21.69 & 24.47 & 21.05 & - \\
\hline Europe & 44.46 & 31.05 & 23.67 & 0.82 \\
\hline
\end{tabular}

Income is defined as equivalised disposable household income and PPP-adjusted (EU-28 = 1). The income reference year for Germany is 2013. Cross-sectional weights from the EU-SILC are used

Malta had to be excluded because it does not report information about the age of individuals

${ }^{\text {a }}$ The household head is defined as the person with the highest income of at least 18 years of age. When two household members have the same income, the oldest person is chosen to be the household head 
Table 8 Sources of income inequality in the EU-28 by country group and demographic type, 2014. Source: Own calculations, EU-SILC 2014 \& 2015

\begin{tabular}{|c|c|c|c|c|}
\hline \multirow[t]{2}{*}{ Country group } & \multicolumn{3}{|c|}{ Age of the household head ${ }^{a}$} & \multirow[t]{2}{*}{ All } \\
\hline & $\begin{array}{l}<60 \text {, with- } \\
\text { out children }\end{array}$ & $<60$, children & $\geq 60$ & \\
\hline $\mathrm{BC}$ & 0.214 & 0.248 & 0.198 & 0.233 \\
\hline CEE & 0.164 & 0.132 & 0.175 & 0.158 \\
\hline EEC & 0.190 & 0.214 & 0.311 & 0.223 \\
\hline LME & 0.192 & 0.152 & 0.151 & 0.175 \\
\hline $\mathrm{MC}$ & 0.188 & 0.202 & 0.205 & 0.199 \\
\hline SDC & 0.137 & 0.100 & 0.139 & 0.125 \\
\hline Europe & 0.215 & 0.200 & 0.229 & 0.215 \\
\hline
\end{tabular}

Income is defined as equivalised disposable household income and PPP-adjusted (EU-28 = 1). The income reference year for Germany is 2013. Cross-sectional weights from the EU-SILC are used

Malta had to be excluded because it does not report information about the age of individuals

${ }^{\text {a }}$ The household head is defined as the person with the highest income of at least 18 years of age. When two household members have the same income, the oldest person is chosen to be the household head

hh with children. Interestingly, in Estonia the overall Theil index is higher than the indices of each demographic subgroup. When comparing the mean incomes of each subgroup in Estonia, it is detected that they vary tremendously between $9805 €$ for hh above 59 years and $13,945 €$ for hh without children. Thus, it seems that betweendemographic-group inequality is responsible that overall inequality exceeds inequality within any of the three demographic groups.

In addition, the results in Table 7 show that between-country inequality (21.7\%) contributes more to the overall inequality of the EU-28 than between-demographicgroup inequality $(0.82 \%)$. Moreover, hh without children account for about two fifths $(44.46 \%)$ of the overall inequality, followed by hh with children $(31.05 \%)$ and hh above 59 years (23.67\%). However, there are differences among countries regarding the contribution of each demographic group. The contribution of hh above 59 years ranges from around $10 \%$ in Slovakia to around $60 \%$ in Romania. The same holds true for hh without children, for which the range lies between around $20 \%$ in Romania and around 52\% in Germany. Finally, the span for hh with children ranges from around $19 \%$ in Romania to around $45 \%$ in Ireland. These findings illustrate that inequality within demographic groups as well as their contribution to overall inequality vary tremendously among member states. In 15 countries inequality is highest for household heads older than 59 years, whereas the remaining countries show their peaks in households with household heads younger than 60 years.

\subsubsection{Demographic groups on country group level}

Table 8 presents the results on country group level and shows that SDC have the lowest income inequality among all demographic groups. Income inequality for hh 
Table 9 Contribution to income inequality in the EU-28 by country group and demographic group, 2014. Source: Own calculations, EU-SILC 2014 \& 2015

\begin{tabular}{|c|c|c|c|c|}
\hline \multirow[t]{3}{*}{ Country group } & \multicolumn{4}{|c|}{ Contribution to country group inequality in $\%$} \\
\hline & \multicolumn{3}{|c|}{ Age of the household head ${ }^{\mathrm{a}}$} & \multirow{2}{*}{$\begin{array}{l}\text { Variation } \\
\text { between } \\
\text { hh }\end{array}$} \\
\hline & $\begin{array}{l}<60 \\
\text { without } \\
\text { children }\end{array}$ & $<60$, children & $\geq 60$ & \\
\hline $\mathrm{BC}$ & 41.56 & 41.05 & 13.54 & 3.85 \\
\hline CEE & 45.94 & 27.08 & 26.27 & 0.70 \\
\hline EEC & 38.82 & 35.53 & 24.67 & 0.98 \\
\hline LME & 49.53 & 30.70 & 16.64 & 3.13 \\
\hline $\mathrm{MC}$ & 42.38 & 32.24 & 24.35 & 1.02 \\
\hline SDC & 44.68 & 28.85 & 25.63 & 0.83 \\
\hline $\begin{array}{l}\text { Variation between } \\
\text { country groups, } \\
\%\end{array}$ & 18.33 & 20.37 & 17.56 & - \\
\hline Europe & 44.46 & 31.05 & 23.67 & 0.82 \\
\hline
\end{tabular}

Income is defined as equivalised disposable household income and PPP-adjusted (EU-28 = 1). The income reference year for Germany is 2013. Cross-sectional weights from the EU-SILC are used

Malta had to be excluded because it does not report information about the age of individuals

${ }^{\text {a }}$ The household head is defined as the person with the highest income of at least 18 years of age. When two household members have the same income, the oldest person is chosen to be the household head

above 59 years is highest in EEC (0.311), while BC have the highest inequality for hh without $(0.214)$ and with $(0.248)$ children. Interestingly, the same as on country level, income inequality among country groups ranges most for hh above 59 and least for hh without children. This demonstrates differences in income inequality for the elderly among the countries of the EU-28. However, this result is not surprisingly as the pension system reflects former differences in incomes of the elderly and therefore works as a mirror of income inequality in the past.

Furthermore, Table 9 shows the contribution of demographic subgroups to country group inequality. The results illustrate that in all country groups, hh without children contribute the most, while hh above 59 years contribute the least to total income inequality. Nevertheless, the contribution of each demographic group varies among country groups. Households older than 59 years account for $13.54 \%$ of inequality in BC, compared to $26.27 \%$ in CEE. Moreover, the contribution for hh with children varies between $27.08 \%$ in $\mathrm{CEE}$ and $41.05 \%$ in BC.

Thus, the results show a heterogeneous situation regarding income inequality and the contribution of demographic groups to inequality among countries and country groups. However, it is shown that SDC have the lowest inequality among all demographic groups. To analyse the relationship between social expenditures and income inequality, this study follows Beblo and Knaus (2001) and illustrates the correlation between social security expenditures in percent of GDP and country-Theils in Fig. 3. 


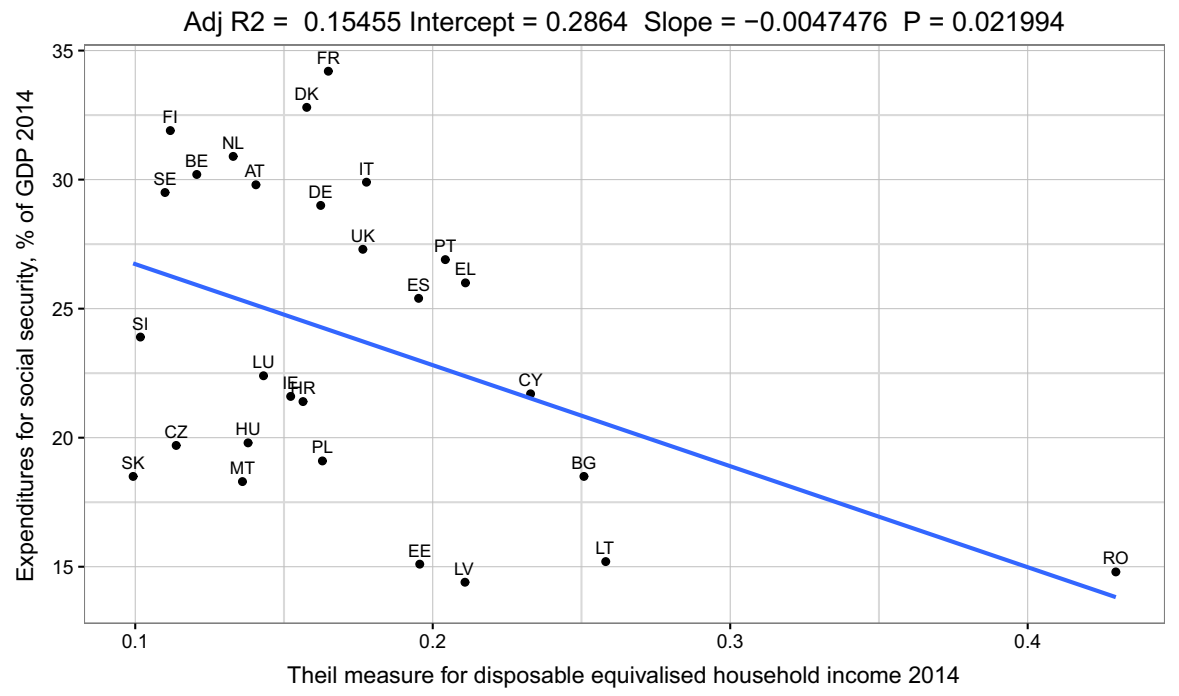

Fig. 3 The relationship between social expenditures and income inequality among countries, 2014. Notes Income is defined as equivalised disposable household income and PPP-adjusted (EU-28 =1). The income reference year for Germany is 2013. Cross-sectional weights from the EU-SILC are used. This figure illustrates a significant negative relationship between social expenditures for social security and the value of the Theil index. Source: Own calculations, EU-SILC 2014 \& 2015, Eurostat

The results find a significant negative relationship between the two and show that the lower social expenditures of a member state regarding its GDP, the higher is its income inequality and vice versa.

\section{The decomposition of the European income inequality before transfers and taxes}

This section tackles the second research question and analyses the composition of income inequality before transfers and taxes. Therefore, the Theils ${ }^{16}$ of equivalised market household income (before transfers and taxes) and equivalised disposable household income (after transfers and taxes) are compared. ${ }^{17}$ The results provide insights about how the composition of income inequality for the EU-28 changes after transfers and taxes at the national level. However, it has to be mentioned that this study only focuses on the effect of transfers and taxes. Castles et al. (2012) list various other characteristics of the welfare state that have

\footnotetext{
16 The nature of the Theil allows to consider only incomes greater than zero. Calculating pre-transfer Theil indices would therefore lead to a loss of many observations as a great number of individuals do not consider any market income. To have a balanced sample when comparing pre-transfer and post-transfer Theil indices, each individual with a market income of zero gets an artificial income of $1 \times 10^{-8}$.

17 For simplicity income before transfers and taxes is described as pre-transfers and incomes after transfers and taxes is described as post-transfers.
} 
Table 10 Sources of income inequality in the EU-28 before and after government redistribution by country, 2014. Source: Own calculations, EU-SILC 2014 \& 2015

\begin{tabular}{|c|c|c|c|c|}
\hline Country & Pre-transfer Theil ${ }^{\mathrm{a}}$ & $\begin{array}{l}\text { Pre-transfer } \\
\text { share }^{c}(\%)\end{array}$ & $\begin{array}{l}\text { Post-transfer } \\
\text { Theil }^{\mathrm{b}}\end{array}$ & $\begin{array}{l}\text { Post-trans- } \\
\text { fer share } \\
(\%)\end{array}$ \\
\hline $\mathrm{AT}$ & 0.469 & 2.0 & 0.141 & 1.5 \\
\hline $\mathrm{BE}$ & 0.464 & 2.3 & 0.121 & 1.5 \\
\hline BG & 0.469 & 0.6 & 0.251 & 0.8 \\
\hline CY & 0.434 & 0.1 & 0.233 & 0.2 \\
\hline $\mathrm{CZ}$ & 0.402 & 1.1 & 0.114 & 0.8 \\
\hline $\mathrm{DE}$ & 0.492 & 19.8 & 0.162 & 15.3 \\
\hline DK & 0.416 & 1.3 & 0.158 & 1.1 \\
\hline $\mathrm{EE}$ & 0.441 & 0.2 & 0.196 & 0.2 \\
\hline EL & 0.630 & 1.5 & 0.211 & 1.2 \\
\hline ES & 0.489 & 7.3 & 0.195 & 7.9 \\
\hline FI & 0.442 & 1.0 & 0.112 & 0.7 \\
\hline FR & 0.454 & 12.5 & 0.165 & 12.0 \\
\hline HR & 0.478 & 0.4 & 0.156 & 0.3 \\
\hline $\mathrm{HU}$ & 0.425 & 0.7 & 0.138 & 0.6 \\
\hline IE & 0.558 & 1.2 & 0.152 & 0.8 \\
\hline IT & 0.483 & 10.6 & 0.178 & 9.8 \\
\hline LT & 0.544 & 0.3 & 0.258 & 0.4 \\
\hline LU & 0.420 & 0.1 & 0.143 & 0.1 \\
\hline LV & 0.446 & 0.2 & 0.211 & 0.2 \\
\hline MT & 0.381 & 0.1 & 0.136 & 0.1 \\
\hline NL & 0.442 & 3.8 & 0.133 & 2.5 \\
\hline PL & 0.418 & 3.6 & 0.163 & 3.5 \\
\hline PT & 0.565 & 1.5 & 0.204 & 1.4 \\
\hline $\mathrm{RO}$ & 0.537 & 1.1 & 0.430 & 2.3 \\
\hline SE & 0.357 & 1.6 & 0.110 & 1.2 \\
\hline SI & 0.399 & 0.3 & 0.102 & 0.2 \\
\hline SK & 0.311 & 0.4 & 0.099 & 0.3 \\
\hline UK & 0.534 & 14.4 & 0.177 & 11.6 \\
\hline Between countries & 0.054 & 10.1 & 0.047 & 21.7 \\
\hline Europe & 0.533 & 100 & 0.215 & 100 \\
\hline
\end{tabular}

All income are PPP-adjusted $(E U-28=1)$. The income reference year for Germany is 2013. Cross-sectional weights from the EU-SILC are used

${ }^{a}$ Income is defined as equivalised market household income

${ }^{\mathrm{b}}$ Income is defined as equivalised disposable household income

${ }^{\mathrm{c}}$ The share represents the contribution of a country to the overall inequality of the EU-28 
Table 11 Sources of income inequality in the EU-28 before and after government redistribution by country group, 2014. Source: Own calculations, EU-SILC 2014 \& 2015

\begin{tabular}{|c|c|c|c|c|}
\hline Country & Pre-transfer Theil $1^{\mathrm{a}}$ & $\begin{array}{l}\text { Pre-transfer share }{ }^{\mathrm{c}} \\
(\%)\end{array}$ & $\begin{array}{l}\text { Post-transfer } \\
\text { Theil }^{\text {b }}\end{array}$ & $\begin{array}{l}\text { Post-trans- } \\
\text { fer share } \\
(\%)\end{array}$ \\
\hline $\mathrm{BC}$ & 0.493 & 0.7 & 0.233 & 0.8 \\
\hline CEE & 0.474 & 40.8 & 0.158 & 33.0 \\
\hline EEC & 0.474 & 8.9 & 0.223 & 10.7 \\
\hline LME & 0.535 & 15.6 & 0.175 & 12.5 \\
\hline MC & 0.507 & 21.4 & 0.198 & 21.7 \\
\hline SDC & 0.403 & 4.0 & 0.125 & 2.9 \\
\hline $\begin{array}{l}\text { Between country } \\
\text { group }\end{array}$ & 0.046 & 8.6 & 0.040 & 18.4 \\
\hline Europe & 0.533 & 100 & 0.215 & 100 \\
\hline
\end{tabular}

All income are PPP-adjusted (EU-28 $=1$ ). The income reference year for Germany is 2013. Cross-sectional weights from the EU-SILC are used

${ }^{a}$ Income is defined as equivalised market household income

${ }^{\mathrm{b}}$ Income is defined as equivalised disposable household income

${ }^{\mathrm{c}}$ The share represents the contribution of a country group to the overall inequality of the EU-28

redistributive effects and would be relevant for income inequality, such as the health care system, family benefits and education.

The results in Table 10 illustrate that after transfers and taxes income inequality in the EU-28 decreases from 0.533 (pre-transfers) to 0.215 (post-transfers). Nevertheless, the relative contribution of between-country inequality increases from $10.1 \%$ (pre-transfers) to $21.7 \%$ (post-transfers). Analysing the country group level shows the same results. Table 11 illustrates that all country groups reduce their inequality after transfers and taxes. However, the relative contribution of between-country-group inequality increases tremendously from $8.6 \%$ (pre-transfers) to $18.4 \%$ (post-transfers).

Thus, this study follows the conjecture of Beblo and Knaus (2001) who assume "[...] that richer countries have more extensive social protection schemes in order to lower the gap between high and low income earners" (Beblo and Knaus 2001, p. 317) and tests their hypothesis for the countries of the EU-28. Hence, Fig. 4 compares the relationship between post-transfer annual mean incomes and (a) inequality, (b) expenditures for social security and (c) redistribution.

Figure 4 illustrates three correlations on country level and show that the higher the post-transfer annual mean income: (1) the lower is income inequality, (2) the higher are expenditures for social security with regard to GDP and (3) the higher is the relative reduction of the Theil index after transfers and taxes. Figure 5 illustrates the same results on country group level and shows that country groups split into two poles. CEE, LME and SDC show the highest annual mean incomes, social expenditures and reduction in inequality, while $\mathrm{BC}$ and $\mathrm{EEC}$ show the opposite result. MC lie between these two extremes. 

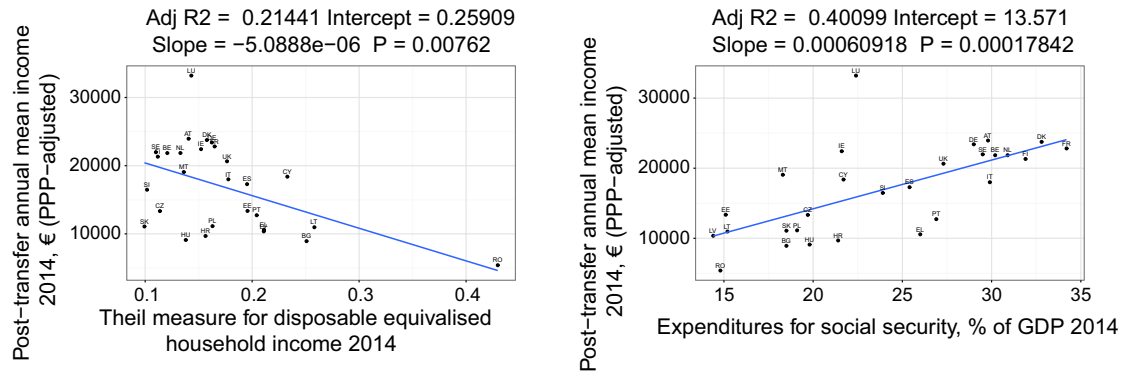

(a) Post-transfer mean incomes and income inequality

(b) Post-transfer mean incomes and social expenditures

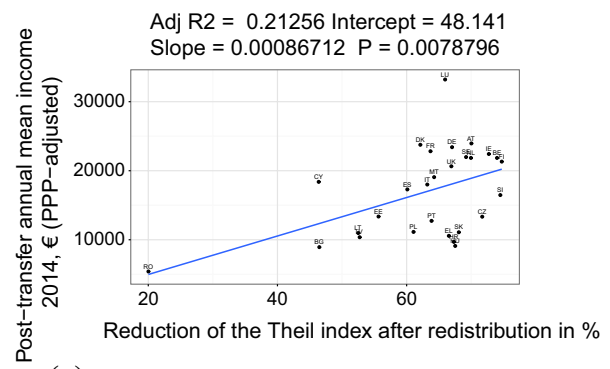

(c) Post-transfer mean incomes and redistribution

Fig. 4 The relationship between post-transfer annual mean incomes and redistribution among countries, 2014. a This figure illustrates a significant negative relationship between annual mean incomes and the amount of income inequality, $\mathbf{b}$ this figure illustrates a significant positive relationship between annual mean incomes and expenditures for social security, $\mathbf{c}$ this figure illustrates a significant positive relationship between annual mean incomes and the reduction of income inequality due to government redistribution. Notes Income is defined as equivalised disposable household income and PPP-adjusted (EU$28=1$ ). The income reference year for Germany is 2013. Cross-sectional weights from the EU-SILC are used. Source: Own calculations, EU-SILC 2014 \& 2015, Eurostat

To summarise, the results support the conjecture of Beblo and Knaus (2001) and show that high income countries have lower inequality, invest more in social expenditures and relatively reduce inequality at a larger extent after transfers and taxes than low income countries. However, it has to emphasised that these are no causal relationships but correlations.

\section{Conclusion}

In this paper the composition of income inequality in the EU-28 for 2014 is analysed in two steps. First, income inequality is decomposed into a within- and betweencomponent by three subgroups, which are defined as countries, country groups and demographic groups. In a second step, it is analysed how the composition of income inequality changes after transfers and taxes. For the empirical analysis this paper uses the Theil index, an inequality measure that is additively decomposable. It uses data from the European Survey on Income and Living Conditions, which includes income data for over half a million observations for the year 2014. 


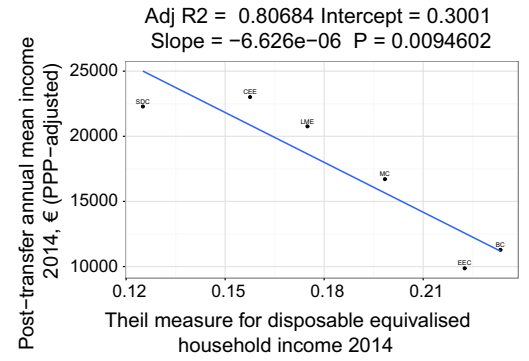

(a) Post-transfer mean incomes and inequality

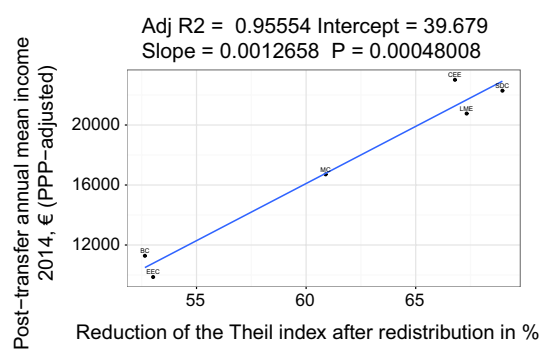

(c) Post-transfer mean incomes and redistribution

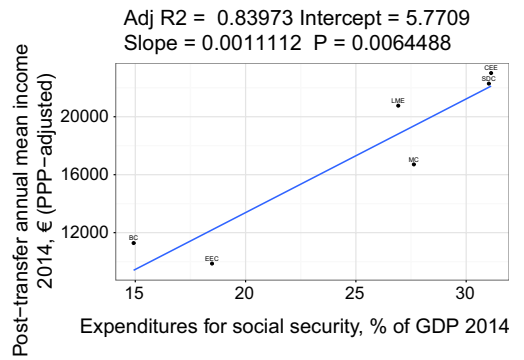

(b) Post-transfer mean incomes and social expenditures

Fig. 5 The relationship between post-transfer annual mean incomes and redistribution among country groups, 2014. a This figure illustrates a significant negative relationship between annual mean incomes and the amount of income inequality, $\mathbf{b}$ this figure illustrates a significant positive relationship between annual mean incomes and expenditures for social security, $\mathbf{c}$ this figure illustrates a significant positive relationship between annual mean incomes and the reduction of income inequality due to government redistribution. Notes Based on Aristei and Perugini (2015), countries are clustered into country groups with regard to similar socio-economic policies and institutions. Income is defined as equivalised disposable household income and PPP-adjusted (EU-28 =1). The income reference year for Germany is 2013. Cross-sectional weights from the EU-SILC are used. Source: Own calculations, EU-SILC 2014 \& 2015, Eurostat

Decomposing income inequality in the EU-28 shows that between-country inequality contributes around $21.7 \%$, whereas within-country inequality contributes $78.3 \%$ to the aggregated Theil index of 0.215 . Thus, compared to the results of Papatheodorou and Pavlopoulos (2014), the contribution of between-country differences increases from $4.9 \%$ in 2008 for the EU-15 to $21.7 \%$ in 2014 for the EU-28. Clustering countries into groups with similar socio-economic policies and institutions reveals that income inequality is particularly low in Social-Democratic countries, while Baltic countries show the highest inequality. Income inequality decomposition by demographic groups shows the highest inequality for households with household heads older than 59 years and the lowest income inequality for household heads with children. Furthermore, Social-Democratic countries have the lowest income inequality among all demographic groups. Moreover, after transfers and taxes at the national level, income inequality decreases from 0.533 (pre-transfers) to 0.215 (posttransfers). However, the contribution of between-country inequality increases from $10.1 \%$ (pre-transfers) to $21.7 \%$ (post-transfers). Finally, the results show that high 
income countries have: (1) lower income inequality, (2) higher social expenditures in percent of their GDP and (3) a higher relative reduction of income inequality, than low income countries.

However, to explain causalities and derive specific policy recommendations with regard to the composition of income inequality, future research that analyses the effect of social policy on country level is necessary.

Acknowledgements Open access funding provided by Vienna University of Economics and Business (WU). I thank Wilfried Altzinger, Judith Derndorfer, Michael Ertl, Stefan Humer, Jakob Kapeller, Markus Lampe, Mathias Moser, Christina Neuwirth, Anna Wurm and two anonymous referees for valuable comments.

Open Access This article is distributed under the terms of the Creative Commons Attribution 4.0 International License (http://creativecommons.org/licenses/by/4.0/), which permits unrestricted use, distribution, and reproduction in any medium, provided you give appropriate credit to the original author(s) and the source, provide a link to the Creative Commons license, and indicate if changes were made.

\section{References}

Aaberge R, Bhuller M, Langørgen A, Mogstad M (2010) The distributional impact of public services when needs differ. J Public Econ 94(9-10):549-562

Almås I (2012) International income inequality: measuring PPP bias by estimating Engel curves for food. Am Econ Rev 102(2):1093-1117

Amable B (2003) The diversity of modern capitalism. Oxford University Press, Oxford

Aristei D, Perugini C (2015) The drivers of income mobility in Europe. Econ Syst 39(2):197-224

Atkinson B, Marlier E (2010) Income and living conditions in Europe. Eurostat, Luxembourg

Atkinson AB, Rainwater L, Smeeding TM (1995) Income distribution in OECD countries: evidence from the Luxembourg Income Study'. Social Policy Studies 18, 164p

Beblo M, Knaus T (2001) Measuring income inequality in Euroland. Rev Income Wealth 47(3):301-333

Bohle D, Greskovits B (2007) Neoliberalism, embedded neoliberalism and neocorporatism: towards transnational capitalism in Central-Eastern Europe. West Eur Polit 30(3):443-466

Bourguignon F (1979) Decomposable income inequality measures. Econ J Econ Soc 47(4):901-920

Buhmann B, Rainwater L, Schmaus G, Smeeding TM (1988) Equivalence scales, well-being, inequality, and poverty: sensitivity estimates across ten countries using the Luxembourg Income Study (LIS) database. Rev Income Wealth 34(2):115-142

Burkhauser RV, Smeeding TM, Merz J (1996) Relative inequality and poverty in Germany and the United States using alternative equivalence scales. Rev Income Wealth 42(4):381-400

Castles FG, Leibfried S, Lewis J, Obinger H, Pierson C (2012) The Oxford handbook of the welfare state. Oxford University Press, Oxford

Coates D (2000) Models of capitalism: growth and stagnation in the modern era. Polity Press, Cambridge

Coulter FA, Cowell FA, Jenkins SP (1992) Equivalence scale relativities and the extent of inequality and poverty. Econ J 102(414):1067-1082

Cowell FA (1980) On the structure of additive inequality measures. Rev Econ Stud 47(3):521-531

Cowell FA (2000) Measurement of inequality. Handb Income Distrib 1:87-166

Cowell FA, Mercader-Prats M (1999) Equivalence scales and inequality. In: Silber J (ed) Handbook of income inequality measurement. Springer, Berlin, pp 405-435

Deaton A, Heston A (2010) Understanding PPPs and PPP-based national accounts. Am Econ J Macroecon 2(4):1-35

Drahokoupil J, Hancké B, Rhodes M, Thatcher M (2008) Beyond varieties of capitalism: conflict, contradictions, and complementarities in the European economy. Oxford University Press, Oxford

Eckerstorfer P, Halak J, Kapeller J, Schütz B, Springholz F, Wildauer R (2016) Correcting for the missing rich: an application to wealth survey data. Rev Income Wealth 62(4):605-627

Esping-Andersen G (1990) The three worlds of welfare capitalism. Wiley, New York

Esping-Andersen G, Myles J (2011) Economic inequality and the welfare state. In: Nolan B, Salverda W, Smeeding TM (eds) The Oxford handbook of economic inequality. Oxford University Press, USA 
Eurofound (2017) Income inequalities and employment patterns in Europe before and after the great recession, Research report. Publications Office of the European Union, Luxembourg

Eurostat (2015) People in the EU: who are we and how do we live? Publications Office of the European Union, Luxembourg

Fessler P, Lindner P, Segalla E (2014) Net wealth across the Euro area-why household structure matters and how to control for it (March 13, 2014). ECB Working Paper No. 1663. Available at SSRN: https://ssrn. com/abstract $=2408451$

Fessler P, Rehm M, Tockner L (2016) The impact of housing non-cash income on the household income distribution in Austria. Urban Stud 53(13):2849-2866

Figini P (1998) Inequality measures, equivalence scales and adjustment for household size and composition, Technical report. LIS Working Paper Series

Frick JR, Grabka MM, Smeeding TM, Tsakloglou P (2010) Distributional effects of imputed rents in five European countries. J Hous Econ 19(3):167-179

Gottschalk P, Smeeding TM (1997) Cross-national comparisons of earnings and income inequality. J Econ Lit 35(2):633-687

Hagenaars A, de Vos K, Zaidi AM (1994) Poverty statistics in the late 1980s: research based on micro-data. Office for Official Publications of the European Communities, Luxembourg

Hall PA, Soskice D (2001) Varieties of capitalism: the institutional foundations of comparative advantage. Oxford Universtiy Press, Oxford

Harkness S (2010) The contribution of women's employment and earnings to household income inequality: a cross-country analysis, Technical report. LIS Working Paper Series

Hoffmeister O (2009) The spatial structure of income inequality in the enlarged EU. Rev Income Wealth 55(1):101-127

Jäntti M, Törmälehto V-M, Marlier E (2013) The use of registers in the context of EU-SILC: challenges and opportunities: 2013 Edition, Publications Office

Kilgarriff P, Charlton M, Foley R, O'Donoghue C (2019) The impact of housing consumption value on the spatial distribution of welfare. J Hous Econ 43:118-130

Ku I, Lee W, Lee S, Han K (2018) The role of family behaviors in determining income distribution: the case of South Korea. Demography 55:877-899

Lane D (2007) Post-state socialism: a diversity of capitalisms? In: Lane D, Myant M (eds) Varieties of capitalism in post-communist countries. Palgrave Macmillan, London, pp 13-39

Lohmann H (2011) Comparability of EU-SILC survey and register data: the relationship among employment, earnings and poverty. J Eur Soc Policy 21(1):37-54

Milanovic B (2012) Global inequality recalculated and updated: the effect of New PPP estimates on global inequality and 2005 estimates. J Econ Inequal 10(1):1-18

Nölke A, Vliegenthart A (2009) Enlarging the varieties of capitalism: the emergence of dependent market economies in East Central Europe. World Polit 61(4):670-702

OECD (2013) OECD framework for statistics on the distribution of household income, consumption and wealth. OECD Publishing, Paris

Okamoto M (2012) The relationship between the equivalence scale and the inequality index and its impact on the measurement of income inequality, Technical report. LIS Working Paper Series

Papatheodorou C, Pavlopoulos D (2014) Income inequality in the EU: how do member states contribute? Int J Soc Econ 41(6):450-466

Paturot D, Mellbye K, Brys B (2013) Average personal income tax rate and tax wedge progression in OECD countries, OECD Taxation Working Papers 15. OECD, Paris

Paulus A, Sutherland H, Tsakloglou P (2010) The distributional impact of in-kind public benefits in European countries. J Policy Anal Manag 29(2):243-266

Peichl A, Pestel N, Schneider H (2012) Does size matter? The impact of changes in household structure on income distribution in Germany. Rev Income Wealth 58(1):118-141

Schröder C (2009) Chapter 13 The construction and estimation of equivalence scales and their uses. In: Quantifying consumer preferences. Emerald Group Publishing Limited, pp 349-362

Shorrocks AF (1980) The class of additively decomposable inequality measures. Econ J Econ Soc 48(3):613-625

Smeeding TM, Grodner A (2000) Changing income inequality in OECD countries: updated results from the Luxembourg Income Study (LIS). In: Hauser R, Becker I (eds) The personal distribution of income in an international perspective. Springer, Berlin, pp 205-224

Theil H (1967) Economics and information theory. North Holland Publishing Company, Amsterdam 
Törmälehto V-M, Sauli H (2013) The distributional impact of imputed rent in EU-SILC 2007-2010. Eurostat Statistical Working Papers

Verbist G, Förster MF, Vaalavuo M (2012) The impact of publicly provided services on the distribution of resources: review of new results and methods. OECD Social, Employment and Migration Working Papers, No. 130

Publisher's Note Springer Nature remains neutral with regard to jurisdictional claims in published maps and institutional affiliations. 